\title{
PENDEDERAN UDANG WINDU, Penaeus monodon DALAM TAMBAK TANAH GAMBUT MENGGUNAKAN JENIS PELINDUNG BERBEDA
}

\author{
Muliani") dan Akhmad Mustafa")
}

\begin{abstract}
ABSTRAK
Penelitian ini bertujuan untuk mengetahui pengaruh pemberian pelindung terhadap pertumbuhan, kelangsungan hidup, biomassa dan rasio konversi pakan pada pendederan udang windu di tambak tanah gambut. Luas tambak tanah gambut $500 \mathrm{~m}^{2}$, dengan perlakuan dua jenis pelindung yaitu, pelindung dari daun kelapa dan pelindung dari tali rafia serta tanpa pelindung sebagai kontrol, masing-masing diulang 2 kali. Padat penebaran yang diaplikasikan 500 ekor $/ \mathrm{m}^{2}$ yang dideder selama 20 hari.

Hasil penelitian menunjukkan bahwa jenis pelindung yang dicobakan berpengaruh tidak nyata $(P>0,05)$ terhadap bobot, panjang, biomassa, dan rasiokonversi pakan tetapi berpengaruh nyata $(P<0,05)$ terhadap kelangsungan hidup udang windu. Kelangsungan hidup tertinggi $(80,90 \%)$ didapatkan pada pendederan udang windu yang diberi pelindung dari tali rafia dan terendah $(48,90 \%)$ yang diberi pelindung dari daun kelapa.

ABSTRACT: Nursery Rearing of Tiger Prawn, Penaeus monodon in Peat Soil Pond using Different Shelters, by: Muliani and Akbmad Mustafa.

This experiment aimed at determine the effect of different shelter on growth rate, survival rate, biomass, and feed conversion ratio in nursery rearing of tiger prawn in peat soil pond. The experiment was conducted in pond of $500 \mathrm{~m}^{2}$. The different shelters used as treatments were coconut leaf and plastic rope, while unsheltered ponds were use as control each with two replications. Stocking density was is $500 \mathrm{ind} . / \mathrm{m}^{2}$ and reared for 20 days. Results of the experiment showed that different shelters gave no significant effect on the growth rate, biomass, and feed conversion ratio, but there were significant effect on the survival rate of tiger prawn. The highest survival rate $(80.90 \%)$ of tiger prawn was achieved by using plastic rope shelter and the lowest one $(48.90 \%)$ was achieved from ponds using coconut leaf shelter.
\end{abstract}

KEYWORDS: Nursery rearing, peat soil pond, sbelter, swrvival rate, growtb rate, Tiger prawe

\section{PENDAHULUAN}

Masalah yang sering timbul pada budidaya udang windu adalah tingginya tingkat kematian udang. Hal ini sering dikeluhkan oleh pengusaha tambak intensif, semiintensif maupun ekstensif. Kasus kehilangan udang pada bulanbulan pertama pemeliharaan tanpa diketahui penyebabnya sering menimbulkan praduga yang bermacam-macam.

*) Peneliti pada Balai Penelitian Perikanan Pantai, Maros 
Jika ditelusuri lebih jauh, kematian udang bukan semata-semata disebabkan oleh serangan penyakit, tetapi juga oleh kurangnya pengetahuan tentang teknik budidaya, khususnya yang terkait dengan sifat-sifat biologi udang. Benur yang berasal dari panti benih di mana semua faktor lingkungan dapat dikontrol, oleh petani sering langsung ditebar ke tambak tanpa melakukan penyesuaian lingkungan terlebih dahulu. Hal ini menyebabkan stres bagi benur sehingga mudah terserang penyakit (Liu, 1989; Rukyani, 1993), atau bahkan mengalami kematian jika perbedaan kualitas air terlalu menjolok dengan air asal benur. Selain itu ukuran benur yang ditebar juga sering tidak mendapat perhatian oleh petani, sementara hal ini sangat berperan terhadap daya tahan benur terhadap faktor-faktor lingkungan (Shigueno, 1970 dalam Martosudarmo, 1989; Ilyas et al., 1987).

Pendederan benur windu merupakan salah satu usaha untuk menekan angka kematian udang di tambak, karena udang yang telah dideder memiliki vitalitas (daya tahan) yang lebih baik, sebagai hasil seleksi selama pendederan atau pembantutan (Mangampa et al., 1990; Mustafa dan Mangampa, 1990), selain itu dengan pendederan dapat diperoleh ukuran benur yang relatif sama dan lebih besar, di mana ukuran benur yang ideal ditebar di tambak pembesaran adalah sekitar $2 \mathrm{~cm}$ (Ilyas et al., 1987). Pendederan dan atau pembantutan pada tambak tanah mineral telah banyak dilakukan (Tjaronge et al., 1987; Mangampa et al., 1990; Mustafa dan Mangampa, 1990; Mangampa dan Mustafa, 1992a dan 1992b), begitu pula pemeliharaan pascalarva udang windu dalam bak fiberglass dan akuarium (Suwirya dan Daulay, 1986; Suwirya et al., 1986; Ahmad et al., 1987; Yacob et al., 1987; Palinggi, 1993; Suwirya, 1993) dengan berbagai perlakuan. Pada tambak tanah gambut belum ada data yang akurat, sementara tambak tanah gambut memiliki permasalahan yang jauh lebih kompleks yang menjadi faktor utama keberhasilan usaha budidaya. Mengacu dari hal tersebut maka perlu dilakukan penelitian pendederan udang windu pada tambak tanah gambut. Pemberian pelindung dalam pendederan udang windu merupakan salah satu aspek yang perlu diteliti. Hal ini berdasarkan pada kondisi dasar tambak tanah gambut yang biasanya jelek sehingga benur windu yang dipelihara perlu pelindung yang juga akan menjadi alternatif substrat bagi benur. Beberapa bahan telah digunakan sebagai pelindung dalam pendederan udang windu seperti: daun kelapa (Cholik, 1988; Fernandez, 1979 dalam Martosudarmo, 1989), waring dan krei bambu (Martosudarmo, 1989) dan tali rafia (Lewis, 1989). Daun kelapa dan tali rafia merupakan bahan yang mudah diperoleh dan memiliki bentuk yang relatif sama yang memudahkan dalam pembandingannya.

Penelitian ini bertujuan untuk mengetahui pengaruh pemberian pelindung terhadap pertumbuhan, kelangsungan hidup, dan rasio konversi pakan pada pendederan udang windu di tambak tanah gambut. Hasil penelitian ini diharapkan diperoleh informasi tantang jenis pelindung yang sesuai pada pendederan udang windu di tambak tanah gambut. 


\section{BAHAN DAN METODE}

Penelitian dilakukan pada tambak tanah gambut dengan luas $500 \mathrm{~m}^{2}$ di Dusun Mallekana, Desa Pattiro Sompe, Kecamatan Sibulue, Kabupaten Bone pada bulan Desember 1994 sampai dengan Januari 1995. Perlakuan yang dicobakan adalah perbedaan jenis pelindung yaitu: tanpa pelindung (kontrol), pelindung dari daun kelapa, dan pelindung dari tali rafia, masing-masing dengan 2 ulangan. Pelindung dari daun kelapa maupun tali rafia berjumlah 5 ikat untuk setiap hapa sesuai dengan perlakuan, sedangkan setiap ikatnya terdiri dari 20 lembar yang panjangnya $40 \mathrm{~cm}$. Salah satu ujung pelindung diberi pemberat dari batu dan ditempatkan pada hapa dalam posisi vertikal. Sebelum digunakan, kedua jenis pelindung direndam dalam air tambak selama 2 hari. Sebelumnya daun kelapa dikeringkan selama 2 hari.

Sebagai hewan uji adalah benur windu pascalarva-15 yang diperoleh dari panti benih. Rata-rata bobot dan panjang total benur windu adalah $0,002 \mathrm{~g}$ dan 11,6 mm. Hewan uji ditempatkan dalam hapa berukuran $1 \times 1 \times 1 \mathrm{~m}$, dengan padat penebaran 500 ekor/hapa. Hapa dipasang $10 \mathrm{~cm}$ di atas pelataran tambak dan terendam air sekitar $50 \mathrm{~cm}$, ditempatkan di kiri dan kanan dari titian, jarak antar hapa pada sisi titian yang sama adalah $50 \mathrm{~cm}$, sedangkan jarak hapa dengan titian $30 \mathrm{~cm}$.

Pergantian air sebanyak 10-25\% dilakukan setiap 2-3 hari baik secara gravitasi maupun dengan menggunakan pompa. Pakan yang diberikan adalah pakan udang windu tipe "crumble". Komposisi pakan yang digunakan disajikan pada Table 1. Dosis pakan yang diberikan adalah $100 \%$ dari bobot udang total pada awal penelitian dan menurun menjadi $15 \%$ dari berat total pada akhir penelitian. Pakan diberikan 3 kali sehari yaitu pada pukul 08:00, 16:00 dan 20:00. Pengukuran bobot hewan uji dilakukan setiap 5 hari sekaligus penyesuaian dosis pakan.

Pengambilan contoh tanah secara komposit pada petakan dilakukan pada awal dan akhir penelitan, sedangkan pengambilan contoh air dilakukan setiap 5 hari untuk selanjutnya dianalisis di Laboratorium Kimia Balitkanta Maros. Selain itu, dilakukan pengukuran kualitas air di lapangan pada setiap hari meliputi salinitas, suhu, pH, dan kecerahan. Juga dilakukan pengambilan contoh air untuk analisis plankton pada awal penelitian. Identifikasi plankton dilakukan menurut petunjuk Smith (1950), Yamaji (1966), Newell and Newell (1977), Sachlan (1980) dan Prescot (1983). Analisis bakteri dalam air dilakukan pada awal dan akhir penelitian. Jumlah koloni bakteri dihitung berdasarkan "Total Viable Count" (Austin, 1987), sedangkan jenis bakteri diidentifikasi berdasarkan petunjuk Lewis (1973), modifikasi dari metode Cowan dan Steel (Cowan, 1974), dan Sindermann dan Lightner (1988). 
Table 1. Proximate analysis of the diet in the experiment

\begin{tabular}{lc}
\hline \multicolumn{1}{c}{ Composition } & Percentage \\
\hline Protein & 38.71 \\
Lipid & 6.44 \\
Crude fiber & 1.40 \\
Ash & 10.91 \\
Extract without nitrogen & 38.94 \\
Water & 3.60 \\
\hline
\end{tabular}

Pengamatan oksigen terlarut dan suhu selama 24 jam (selang 4 jam) dilakukan pada pertengahan penelitian. Lama pendederan adalah 20 hari. Kelangsungan hidup udang windu dihitung berdasarkan rumus Rickers (1979), sedangkan rasio konversi pakan dihitung berdasarkan rumus Triono et al. (1992)

Data kelangsungan hidup, pertumbuhan, biomassa, dan rasio konversi pakan yang diperoleh dianalisis ragam dengan menggunakan program MSUSTAT. Peubah yang berbeda nyata diuji lanjut dengan uji Beda Nyata Terkecil, data lainnya dianalisis secara deskriptif.

\section{HASIL DAN PEMBAHASAN}

Pendederan udang windu pada jenis pelindung yang berbeda dengan sistem hapa dalam tambak tanah gambut bukaan baru berpengaruh tidak nyata $(P>0,05)$ terhadap bobot, panjang, biomassa dan rasio konversi pakan udang windu, tetapi berpengaruh nyata $(P<0,05)$ terhadap kelangsungan hidup udang windu (Table 2). Terlihat bahwa, kelangsungan hidup tertinggi $(80,90 \%)$ diperoleh dari pendederan udang windu yang diberi pelindung dari tali rafia, kemudian berturut-turut pada pendederan tanpa pelindung dan pelindung dari daun kelapa masing-masaing 76,95 dan $48,90 \%$. Hasil uji BNT menunjukkan bahwa kelangsungan hidup udang windu yang dideder dengan pelindung dari tali rafia dan tanpa pelindung berbeda tidak nyata, tetapi keduanya berbeda nyata dengan yang diberi pelindung dari daun kelapa. Kelangsungan hidup udang windu yang diperoleh pada penelitian ini relatif lebih tinggi (kecuali yang menggunakan pelindung dari daun kelapa) dibandingkan dengan temuan Tjaronge et al. (1987) yang mendapatkan kelangsungan hidup udang windu sebesar $60,33-67,95 \%$ yang didederkan selama 15 hari pada padat penebaran 700 ekor $/ \mathrm{m}^{2}$ dalam hapa tambak tanah mineral, tetapi relatif lebih rendah jika dibandingkan dengan temuan Martosudarmo (1989) yang mendapatkan 
kelangsungan hidup pascalarva udang windu dengan substrat (pelindung) yang berbeda sebesar 65,14-88,26\%. Hasil temuan Martosudarmo (1989) tersebut menunjukkan bahwa, kelangsungan hidup pascalarva udang windu yang dipelihara dalam hapa sangat dipengaruhi oleh adanya pelindung.

Table 2. Weight, length, survival rate, biomass, and feed conversion ratio of tiger prawn, Penaeus monodon in different shelter, Pattiro Sompe, Bone, December 1994 - January 1995

\begin{tabular}{lccccc}
\hline Kind of shelter & $\begin{array}{c}\text { Weight } \\
(\mathrm{g})\end{array}$ & $\begin{array}{c}\text { Length } \\
(\mathrm{mm})\end{array}$ & $\begin{array}{c}\text { Survival } \\
\text { rate (\%) }\end{array}$ & $\begin{array}{c}\text { Biomass } \\
(\mathrm{g})\end{array}$ & $\begin{array}{c}\text { Feed conversion } \\
\text { ratio }\end{array}$ \\
\hline Without shelter & $0.090^{a}$ & $26.30^{a}$ & $76.95^{a}$ & $35.08^{a}$ & $2.61^{a}$ \\
Coconut leaf & $0.115^{a}$ & $27.30^{a}$ & $48.90^{a}$ & $28.27^{a}$ & $2.64^{a}$ \\
Plastic rope & $0.069^{a}$ & $24.30^{a}$ & $80.90^{a}$ & $27.92^{a}$ & $2.49^{a}$ \\
\hline
\end{tabular}

Note: Numbers with in the same column having the same letter were not significantly different $(P>0.05)$

Rendahnya kelangsungan hidup udang windu pada pendederan yang diberi pelindung dari daun kelapa pada penelitian ini, berbeda dengan temuan sebelumnya seperti yang dilaporkan oleh Cholik (1978) dan Fernandez (1979 dalam Martosudarmo, 1989) masing-masing 94,4 dan 94,13\%. Hal diduga karena daun kelapa yang digunakan belum kering betul (hanya dijemur selama 2 hari) sehingga lebih mudah membusuk.

Kelangsungan hidup udang windu tertinggi $(80,90 \%)$ diperoleh pada pemberian pelindung dari tali rafia. Terlihat tali rafia merupakan pelindung yang tepat dan mempertinggi kelangsungan hidup udang windu, karena tali tersebut dapat digunakan oleh udang windu untuk berlindung terutama pada saat ganti kulit. Adanya pelindung yang sesuai dapat menjadi alternatif lain untuk penempelan udang windu, dan merupakan penyebab lebih tingginya kelangsungan hidup udang windu, mengingat kondisi dasar hapa pada tambak tanah gambut yang cepat menurun.

Kualitas air dalam tambak selama penelitian dapat dilihat pada Table 3. Fluktuasi yang tidak terlalu besar untuk semua parameter merupakan hal yang dapat menekan angka kematian pascalarva udang windu, terutama $\mathrm{pH}$ yang merupakan masalah utama pada tambak tanah gambut, yang berarti berpengaruh pula terhadap kelangsungan hidup organisme yang dipelihara. 
Table 3. Quality of pond water during experiment, Pattiro Sompe, Bone, December 1994 - Januari 1995

\begin{tabular}{lcc}
\hline \multicolumn{1}{c}{ Variables } & & Average $\pm S D$ \\
\hline Salinity & $(p p t)$ & $35.11 \pm 1.87$ \\
Temperature: & $\left({ }^{\circ} \mathrm{C}\right)$ & \\
$\quad-$ Morning & & $28.52 \pm 0.54$ \\
$\quad$ Afternoon & & $32.90 \pm 1.06$ \\
pH : & & \\
$\quad-$ Morning & & $7.58 \pm 0.52$ \\
$\quad$ Afternoon & & $7.80 \pm 0.40$ \\
Sechi disk visual & $(\mathrm{cm})$ & $41.10 \pm 5.00$ \\
Total suspended solid & $(p p m)$ & $1007 \pm 340$ \\
Total organic matter & $(p p m)$ & $8.12 \pm 4.62$ \\
$\mathrm{NO}_{2}-\mathrm{N}$ & $(\mathrm{ppm})$ & $0.0125 \pm 0.0043$ \\
$\mathrm{NO}_{3}-\mathrm{N}$ & $(\mathrm{ppm})$ & $0.0113 \pm 0.0093$ \\
$\mathrm{NH}_{4} \mathrm{~N}$ & $(\mathrm{ppm})$ & $0.0451 \pm 0.0439$ \\
$\mathrm{PO}_{4}-\mathrm{P}$ & $(\mathrm{ppm})$ & $0.0339 \pm 0.0005$ \\
$\mathrm{Fe}$ & $(\mathrm{ppm})$ & $0.2706 \pm 0.0925$ \\
\hline
\end{tabular}

Hasil pengamatan selama 24 jam (selang 4 jam) terhadap oksigen terlarut bahwa konsentrasi terendah (2,20 ppm) terjadi pada pukul 02.00 pada hapa dengan pelindung daun kelapa (Figure 1). Hal ini diduga merupakan salah satu penyebab rendahnya tingkat kelangsungan hidup udang windu. Jika disimak dari kelangsungan hidup, maka pada perlakuan pelindung daun kelapa seharusnya memiliki konsentrasi oksigen terlarut tertinggi karena udang windu yang hidup paling sedikit. Pada kenyataannya justru konsentrasi oksigen terlarut didapatkan lebih rendah pada pelindung daun kelapa. Pada perlakuan tersebut diduga terjadi proses peruraian atau pembusukan daun kelapa yang ikut memanfaatkan oksigen terlarut sehingga menjadi lebih rendah. Konsentrasi oksigen terlarut 2,20 ppm dianggap menghampiri titik kritis bagi udang (Anonim, 1978 dalam Martosudarmo, 1989). Shigueno (1970 dalam Martosudarmo, (1989) melaporkan, kebanyakan udang menderita apabila konsentrasi oksigen terlarut turun sampai 1,8 ppm pada pukul 04.00 .

Suhu air mempunyai pengaruh tehadap pertumbuhan dan kelangsungan hidup udang penaeid. Pada suhu $26-30^{\circ} \mathrm{C}$ pertumbuhan udang penaeid relatif cepat dan kelangsungan hidupnya tinggi (Anonim, 1978 dalam Martosudarmo, 1989). Hasil pengamatan terhadap fluktuasi suhu (Figure 2) masih dalam batas yang dapat ditolerir oleh udang windu, sesuai dengan hasil penelitian Martosudarmo (1989) yang mendapatkan fluktuasi suhu dalam percobaannya rata-rata $26-34^{\circ} \mathrm{C}$, sedangkan Catedral et al. (1977 dalam Martosudarmo, 1989) melaporkan udang penaeid mempunyai toleransi suhu antara $10-37^{\circ} \mathrm{C}$. 
Dissolved oxigen (ppm)

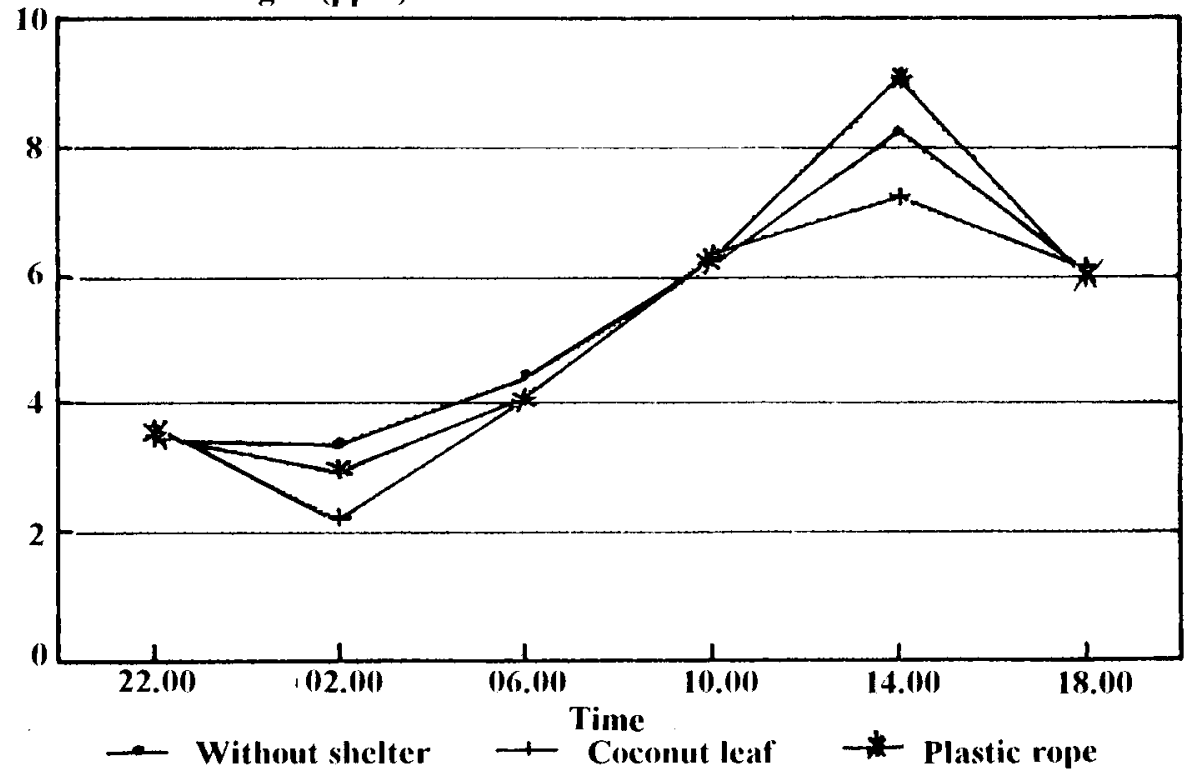

Figure 1. Fluctuation of dissolved oxygen in eacb treatment during 24 bour, Pattiro Sompe, Bone, December 1994

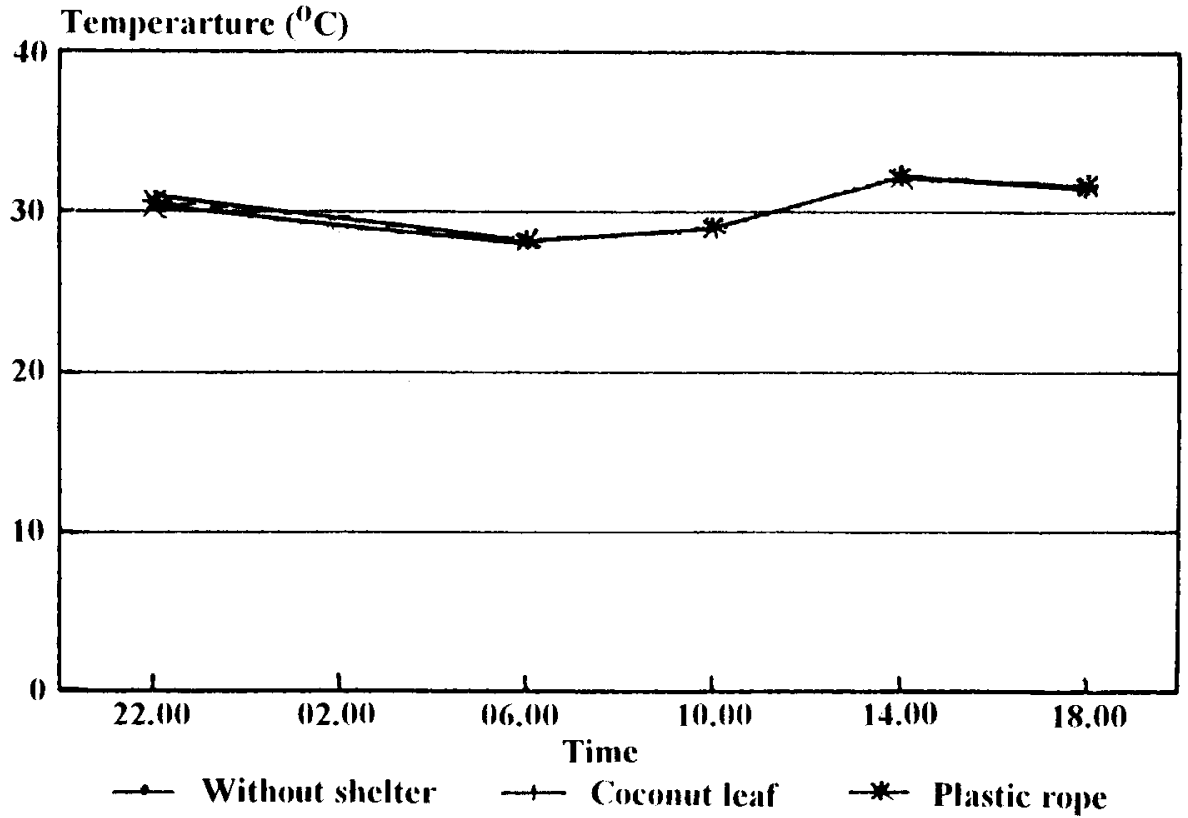

Figure 2. Fluctuation of water temperature in each treatment during 24 bour, Pattiro Sompe, Bone, December 1994 
Dari hasil identifikasi plankton, ditemukan 5 spesies, yang didominasi oleh Brachionus spp. (258 sel/L) kemudian berturut-turut Oscillatoria spp. (149 sel/L), Acartia spp. (88 sel/L), Pleurosigma spp. (33 sel/L), dan Nitzschia spp. (18 sel/L). Kelima spesies plankton yang didapatkan termasuk yang dapat dimanfaatkan sebagai pakan alami oleh udang windu. Namun demikian, kepadatannya lebih rendah dibandingkan dengan temuan Atmomarsono (1992) yang mendapatkan kepadatan fitoplankton 240-576 ind./L di tambak hutan bakau dengan salinitas lebih besar 18 ppt di Kabupaten Karawang (Jawa Barat). Rendahnya kepadatan plankton diduga disebabkan oleh perairan yang tergolong kurang subur, (Table 3) dengan kandungan $\mathrm{NO}_{3}-\mathrm{N}$ dan $\mathrm{PO}_{4}-\mathrm{P}$ (yang merupakan indikator kesuburan) berturut-turut $0,0113 \pm 0,0093 \mathrm{ppm}$ dan $0,0339 \pm 0,0005 \mathrm{ppm}$. Untuk mendukung kehidupan dan pertumbuhan alga dibutuhkan minimal 0,010 ppm $\mathrm{NO}_{3}-\mathrm{N}$ (Chu 1943) dan 0,020 ppm $\mathrm{PO}_{4}-\mathrm{P}$ (Yoshimaru dalam Liaw, 1969)

Kualitas tanah selama penelitian tergolong sangat masam baik pada awal maupun akhir penelitian ( $\mathrm{pH} \mathrm{4,15}$ dan 4,36). Tanah gambut yang digunakan masih dalam tahap reaksi reduksi dengan nilai redoks positif, sedangkan kandungan penyebab kemasaman seperti bahan organik, $\mathrm{Fe}, \mathrm{Al}$, dan $\mathrm{SO}_{4}$ tergolong tinggi (Table 4). Kondisi tanah yang demikian itu merupakan ciri khas tanah gambut (Mustafa et al., 1992) yaitu $\mathrm{pH}$ sangat masam, dengan kandungan bahan organik, Fe, dan Al yang tinggi.

Table 4. Soil quality of peat soil pond (in the beginning and at the end of experiment) used in nursery of tiger prawn with different shelter, Pattiro Sompe, Bone, December 1994 - January 1995

\begin{tabular}{ccc}
\hline Variables & $\begin{array}{c}\text { In the beginning } \\
\text { of experiment }\end{array}$ & At the end of experiment \\
\hline$p H\left(\mathrm{H}_{2} \mathrm{O}\right)$ & 4.2200 & 4.3600 \\
$p H(\mathrm{KCl})$ & 4.1500 & 4.3600 \\
Redox potential (mv) & +252.0000 & +236.0000 \\
$\mathrm{C}$-organic (\%) & 9.2400 & 9.6200 \\
Organic matter (\%) & 15.9300 & 16.5900 \\
$\mathrm{Fe}(\mathrm{ppm})$ & 17.2620 & 17.5890 \\
$\mathrm{Al}(\mathrm{ppm})$ & 6.8200 & 6.1220 \\
$\mathrm{SO}_{4}(\mathrm{ppm})$ & 12.1300 & 12.2920 \\
$\mathrm{P}(\mathrm{ppm})$ & 0.0137 & 0.0135 \\
\hline
\end{tabular}

Dari hasil identifikasi bakteri terhadap contoh air tambak tanah gambut ditemukan 3 jenis bakteri pada awal penelitian dan 2 jenis pada akhir penelitian 
(Table 5). Terlihat bahwa total bakteri pada contoh air berkisar 10-10 $\mathrm{CFU} / \mathrm{mL}$. Meskipun total bakteri yang didapatkan tergolong tinggi namun dianggap tidak membahayakan bagi udang karena ketiga jenis bakteri tersebut merupakan bakteri umum yang sering ditemukan di perairan.

Table 5. Kinds and total number of bacteria in water pond of peat soil in the beginning and the end of the experiment, Pattiro Sompe, Bone, December 1994 - January 1995

\begin{tabular}{lccccc}
\hline Kind of bacteria & \multicolumn{2}{c}{ Initial $(\mathrm{CFU} / \mathrm{ml})$} & \multicolumn{2}{c}{ Final $(\mathrm{CFU} / \mathrm{ml})$} \\
\cline { 2 - 5 } & TSA & TCBSA & TSA & TCBSA \\
\hline- Pseudomonas sp. & $63 \times 10^{5}$ & - & - & - \\
- Acinetobacter sp. & - & $9 \times 10$ & - & $45 \times 10^{5}$ \\
- Enterobacteriaceae & $7 \times 10^{5}$ & - & $11 \times 10^{4}$ & - \\
\hline
\end{tabular}

Note: - TSA (Tryptic Soy Agar)

- TCBSA (Thiosulfate Citrate Bilesalts Sucrose Agar)

\section{KESIMPULAN DAN SARAN}

1. Jenis pelindung yang digunakan berpengaruh nyata terhadap kelangsungan hidup udang windu, tetapi tidak berpengaruh nyata terhadap pertumbuhan, biomassa dan rasio konversi pakan.

2. Kelangsungan hidup udang windu tertinggi $(80,90 \%)$ diperoleh dari perlakuan yang menggunakan pelindung dari tali rafia dan terendah $(48,90 \%)$ pada perlakuan yang menggunakan pelindung dari daun kelapa.

3. Penggunaan pelindung yang tepat dapat mempertinggi kelangsungan hidup udang windu yang didederkan dalam tambak tanah gambut.

4. Perlu dicoba jenis pelindung yang lain dalam pendederan udang windu di tambak tanah gambut dengan menambah padat penebaran.

\section{UCAPAN TERIMA KASIH}

Ucapan terima kasih disampaikan kepada teknisi litkayasa, Saudari Reni Yulianingsih, Dra. Rosiana Sabang, Nurjanna, dan Rifka Pasande, BSc. yang telah banyak membantu dalam penelitian ini baik di lapangan maupun di laboratorium. 


\section{DAFTAR PUSTAKA}

Ahmad, T., H. Kassing, dan M. Tjaronge. 1987. Laju pertumbuhan pascalarva udang windu Penaeus monodon yang diberi pakan berbeda. J. Penel. Budidaya Pantai 3(2):1-7.

Atmomarsono, M. 1992. Faktor penduga kesuburan perairan pada tambak tradisional. J. Penelitian Budidaya Pantai 8(4):73-83.

Austin,B. 1987. Marine microbiology. Cambridge University Press, Cambridge. 222 pp.

Cholik, F. 1978. Study on the effects of different densities of artificial shelters on the survival and growth rate of sugpo fry Penaeus monodon in nursery pond. Unpublished MSc Thesis. UPV College of Fisheries.

Chu, S.P. 1943. The influence of the mineral composition of the medium on the growth of phytoplankton algae. Part II. The influence of the concentration of in organic nitrogen and phosphat phosphorus. The Ecol. 31(2):1-9.

Cowan, S.T. 1974. Cowan and Steel's for identification of medical bacteria. $2^{\text {nd }}$ edition. Cambridge University Press, Cam bridge. 238 pp.

Ilyas, S., F. Cholik, A. Poernomo, W. Ismail, R. Arifudin, T. Daulay, A. Ismail, S. Koesoemadita, I.N.S. Rabegnatar. H. Soepriyadi, H.H. Suharto, Z.I. Azwar, dan S.E. Wardayo. 1987. Petunjuk teknis bagi pengoperasian unit usaha pembesaran udang windu. Seri Pengembangan Hasil Penelitian Perikanan No. PHP/KAN/02/1987. Badan Penelitian dan Pengembangan Perikanan, Jakarta. 100 hal.

Lewis, D. 1973. Predominant aerobic bacteria of fish and shell fish. Texas A and $M$ University, Sea Grant College, Texas

Liaw, W.K. 1969. Chemical and biological studies of fish ponds and reservoirs in Taiwan. Reprinted from Chinese-American Joint Commision Rural Reconstruction Fish. Series No. 7. 43 pp.

Liu, C.I. 1989. Shrimp deseases, prevention and treatment. In Akiyama, D.M. (eds.), Proceedings of the Southeast Asia Shrimp farm Management workshop. Philippines, Indonesia, Thailand. July 26 - August 11, 1989. American Soybean Association, Singapore. p.64-74

Mangampa, M., A. Mustafa, dan A.G. Mangawe. 1990 Penelitian pendahuluan pada budidaya tambak sistem semi-intensif dengan menggunakan benur windu, Penaeus monodon yang di bantut. J. Penel. Budidaya Pantai 6(1):40-46. 
Mangampa, M. dan A. Mustafa. 1992a. Budidaya udang windu, Penaeus monodon pada padat penebaran yang berbeda dengan menggunakan benih yang dibantut. J. Penel. Budidaya Pantai 8(4):37-48.

, dan A. Mustafa 1992b. Penggunaan benur hasil pembantutan dan pengolahan air dan ransum pada budidaya udang windu. Dalam Mansur, H., Rachmansyah, A. , Mustafa, dan A.M. Pirzan. Prosiding Temu Karya Ilmiah Potensi Sumber Daya Kekerangan Sulawesi Selatan dan Sulawesi Tenggara, Watampone, 17-18 Februari 1992. Balai Penelitian Perikanan Budidaya Pantai, Maros. Hal. 137-140.

Martosudarmo, B. 1989. Pengaruh substrat dan pakan yang berbeda terhadap pertumbuhan dan kelulusan hidup pascalarva udang windu, Penaeus monodon produksi pembenihan. Direktorat Jenderal Perikanan bekerja sama dengan International Development Research Centre. 56 hal.

Mustafa, A. dan M. Mangampa. 1990. Usaha budidaya udang tambak menggunakan benur windu, Penaeus monodon yang berbeda lama pembantutannya. J. Penel. Budidaya Pantai 6(2) : 35-48.

Newell, G.E. and R.C. Newell. 1977. Marine plankton: A practical guide.Fifth Edition. Hutchinson dan Co. Ltd., London. 244 pp.

Palinggi, N.N. 1993. Substitusi bungkil kedele dengan ragi dalam pakan pascalarva udang windu, Penaeus monodon J. Penel. Budidaya Pantai 9 (4): $1-8$.

Prescot, G.W. 1983. Algae, of the western great lakes area. Reprinted by Otto Koeltz Science Publisher, W-Germany.

Rickers, W.E. 1979. Growth rate and models. p. 678-743. In Hoar, W. S., D.J. Randall, and J.R. Brett (eds.), Fish Physiology. Vol. VIII. Academic Press, New York.

Rukyani, A. 1993. Penanggulangan penyakit udang windu, Penaeus monodon. Hanafi,A., M. Atmomarsomo, dan S. Ismawati (eds.), Prosiding Seminar Hasil Penelitian Perikanan Budidaya Pantai, Maros, 16-19 juli 1993. Balai Penelitian Perikanan Budidaya Pantai, Maros: 1-8.

Sachlan, M. 1980. Planktonologi. Fakultas Peternakan, Universitas Diponegoro, Semarang. 130 hal.

Sindermann, C.J. and D.V. Lightner. 1988. Disease diagnosis and control in North America Marine Aquaculture. Second (Revised) Edition. Elsevier Scientific Publishing Co., Amsterdam, Oxford, New York. 431 pp.

Smith, G.M. 1950. The freshwater algae of the United States. Mc. Graw-Hill Book Company, Inc., New York, Toronto, London. 719 pp. 
Suwirya, K. dan T. Daulay. 1986. Percobaan pendederan udang windu Penaeus monodon pada substrat yang berbeda. J. Pen. BP 2 (1\&2):30-33.

, Z.I. Azwar, dan T. Rochimat. 1986. Pemeliharaan benur udang windu Penaeus monodon dengan berbagai tingkat kadar garam dalam kondisi laboratorium. J. Pen.BP 2 (1\&2):34-39.

, 1993. Pengaruh kadar asam lemak esensial dalam pakan terhadap pertumbuhan pascalarva udang windu, Penaeus monodon. J. Penelitian Budidaya Pantai 9 (4):9-14.

Tjaronge, M., M. Mangampa, dan A.M. Pirzan. 1987. Pemanfaatan kerang sebagai pakan udang windu Penaeus monodon. J. Pen. Budidaya Pantai 3(1):16-21.

Triono, A.T., Penaflorida, V.D., and Bolivar, E.C. 1992. Growth and Survival of Penaeus monodon Juvenils. Feed a Diet Lacking Vitamin Supplements in Modified Extensive Culture System. Aquaculture 101:25-32

Yacob, M.J.R. dan N.N. Palinggi. 1987. Pengaruh pemberian pakan dari berbagai sumber protein terhadap laju pertumbuhan dan kelulusan hidup benur udang windu (Penaeus monodon). J. Penel. Budidaya Pantai 3(2):8-18.

Yamaji, I. 1966. Illustrations of the marine plankton of Japan. Hoikusha Publishing Co. Ltd, Japan. 369 p. 